\title{
Pengaruh Penggunaan Media Sosial (Medsos) Secara Positif Terhadap Motivasi Belajar Siswa SD Negeri Perumnas Kecamatan Rappocini Kota Makassar
}

\author{
Muhammad Irfan ${ }^{1}$, Siti Nursiah ${ }^{2}$, Andi Nilam Rahayu ${ }^{3}$ \\ 1,2,3 Pendidikan Guru Sekolah Dasar, Fakultas Ilmu Pendidikan, Universitas Negeri Makassar \\ ${ }^{1}$ irfanunm@gmail.com \\ ${ }^{2}$ stnursiah24@gmail.com \\ 3andinilam98@gmail.com
}

\begin{abstract}
ABSTRAK
Penelitian ini mengkaji mengenai pengaruh penggunaan media sosial (medsos) secara positif terhadap motivasi belajar siswa SD Negeri Perumnas Kecamatan Rappocini Kota Makassar. Masalah dalam penelitian ini adalah bagaimanakah pengaruh penggunaan media sosial secara positif terhadap motivasi belajar siswa SD Negeri Perumnas Kecamatan Rapocini Kota Makassar. Tujuan penelitian adalah untuk mengetahui pengaruh penggunaan media sosial secara positif terhadap motivasi belajar siswa SD Negeri Perumnas Kecamatan Rappocini Kota Makassar. Penelitian ini menggunakan pendekatan kuantitatif dengan jenis penelitian ex-postfacto. Penelitian ini menggunakan desain penelitian causal comparative research dengan teknik purpossive sampling. Sampel yang digunakan dalam penelitian ini adalah seluruh siswa kelas IV dan V dengan jumlah siswa sekitar 51 orang pada SD Negeri Perumnas Kecamatan Rappocini Kota Makassar. Teknik pengumpulan data menggunakan instrumen penelitian kuisioner, wawancara dan dokumentasi. Hasil penelitian menunjukkan bahwa analisis statistik penggunaan media sosial berada pada kategori tinggi sedangkan motivasi belajar siswa berada pada kategori sangat tinggi. Hasil analisis statistik inferensial menunjukkan bahwa terdapat pengaruh yang positif dan signifikan penggunaan media sosial secara positif terhadap motivasi belajar siswa SD Negeri Perumnas Kecamatan Rappocini Kota Makassar.
\end{abstract}

Kata kunci: Media Sosial, Motivasi Belajar

\begin{abstract}
This study examines the effect of the positive use of social media (facebook and whatsapp) on students' learning motivation at SD Negeri Perumnas, Kecamatan Rappocini , Kota Makssar. The problem in this study is there an effect of using social media (sosmed) positively on student learning motivation at SD Negeri Perumnas, Kecamatan Rappocini, Kota Makassar ?. The purpose of this study was to determine the effect of the use of social media positively on the motivation of students of SD Negeri Perumnas, Kecamatan Rappocini, Kota Makssar. This research used a quantitative approach with the type of ex-postfacto. This research design used causal comparative research with purpossive sampling technique. The sample used in this study were all students of grade IV and V with amount of the students about 51 at SD Negeri Perumnas, Kecamatan Rappocini, Kota Makassar. Data collection techniques used research questionnaire instruments, interviews and documentation. The results showed that the statistical analysis of the wise use of social media was in the high category while the students' motivation was in the very high category. The results of inferential statistical analysis showed that the use of social media positively has a positive effect on student learning motivation.
\end{abstract}

Keywords: Social Media, Learning Motivation

\section{PENDAHULUAN}

Perkembangan Teknologi Informasi dan Komunikasi (TIK) di era revolusi industri 4,0 saat ini semakin berkembang pesat. Undang-undang Republik Indonesia No. 19 Tahun 2016 tentang perubahan atas undangundang No. 11 Tahun 2008 tentang Informasi dan Transaksi Elektronik Pasal 1 ayat 1 menyatakan bahwa : Informasi Elektronik adalah satu atau sekumpulan data elektronik, termasuk tetapi tidak terbatas pada tulisan, suara, gambar, peta, rancangan, foto, Electronic Data Interchange (EDI), surat elektronik (electronic mail), telegram, teleks, 
telecopy atau sejenisnya, huruf, tanda, angka, kode akses, simbol, atau perforasi yang telah diolah yang memiliki arti atau dapat dipahami oleh orang yang mampu memahaminya.

$$
\text { Berdasarkan survei Asosiasi }
$$

Penyelenggara Jasa Internet (APJII) Indonesia tahun 2019 menyebutkan bahwa tahun 2017 yang lalu angka penetrasi pengguna internet di Indonesia meningkat sekitar 8 persen menjadi 143,26 juta jiwa yang setara dengan 54,68 persen dari seluruh populasi di Indonesia. Ternyata tahun 2019 ini, angka penetrasi pengguna internet di Indonesia meningkat lagi sekitar 10,12 persen menjadi 171,17 juta jiwa. Angka ini setara dengan 64,8 persen dari seluruh populasi yang ada yakni 264 juta jiwa. Hasil survei menyebutkan bahwa pengguna terbesar adalah masyarakat dengan rentang usia 15 sampai 19 tahun. Hal ini berarti masyarakat dari kalangan anak-anak dan remaja masih menjadi pengguna internet terbesar dari tahun 2017 yang lalu, dimana saat itu hasil (Survei APJII, 2017)menyebutkan penetrasi pengguna internet berdasarkan usianya meliputi umur 13-18 tahun sebesar 75,50 persen.

Hasil survei APJII tersebut sejalan dengan pengamatan yang telah dilakukan dan pengalaman empiris penulis pada tanggal 20 Februari 2019, di SD Negeri Perumnas Kecamatan Rappocini Kota Makassar, peneliti menemukan bahwa hampir seluruh siswa kelas tinggi yakni 4,5 dan 6 sebanyak 81 orang siswa memiliki dan menggunakan media sosial seperti facebook dan whatsapp. Dari hasil pengamatan ditemukan sekitar $13,58 \%$ siswa menggunakan media sosial whatsapp milik pribadi, 6,17\% siswa menggunakan media sosial facebook milik pribadi, $64,19 \%$ siswa menggunakan media sosial facebook dan whatsapp milik pribadi, $7,40 \%$ siswa menggunakan media sosial facebook atau whatsapp milik orangtuanya, dan $8,66 \%$ siswa tidak menggunakan media sosial facebook maupun whatsapp. Berdasarkan persentase tersebut, maka peneliti hendak meneliti tentang penggunaan media sosial facebook dan whatsapp pada siswa kelas tinggi SD Negeri Perumnas Kecamatan Rappocini Kota Makassar.

Hasil penelitian yang dilakukan oleh (Chalim \& Anwas, 2018) menunjukkan bahwa terdapat hubungan yang signifikan dan positif antara intensitas bimbingan orangtua dalam belajar terhadap pemanfaatan internet sebagai sumber belajar. Selain itu, intensitas guru memberikan tugas-tugas pelajaran untuk memanfaatkan internet berhubungan positif dan signifikan. Dengan demikian, media sosial dapat mengambil peran sebagai media dalam pendidikan yang mampu meningkatkan motivasi belajar peserta didik. Hasil penelitian yang dilakukan oleh (Permana, 2018) menunjukkan bahwa terdapat pengaruh penggunaan media sosial sebagai sumber belajar terhadap motivasi belajar siswa. Hasil penelitian ini membuktikan bahwa media sosial tidak hanya membawa pengaruh negatif, tetapi juga berpengaruh positif pada peningkatan motivasi belajar siswa bergantung pada penggunaannya. Menurut (Aspari, 2016) "media sosial menjadikan terbentuknya komunitas pertemanan yang luas, sehingga mampu memotivasi para siswa dalam mengembangkan diri dari materi atau masukan teman-teman baru mereka yang terhubung secara online".

Berdasarkan pernyataan dari beberapa teori dan hasil penelitian tersebut, peneliti mengajukan penelitian untuk mengkaji "Pengaruh Penggunaan Media Sosial (Medsos) Secara Bijak Terhadap Motivasi Belajar Siswa SD Negeri Perumnas Kecamatan Rappocini Kota Makassar".

\section{Media Sosial}

Media sosial sendiri terdiri dari dua kata yaitu "media" dan "sosial". Rohani (2014) mengemukakan bahwa media adalah segara sesuatu yang dapat diindrakan yang berfungsi sebagai proses komunikasi antara komunikator dan komunikan. Ratnamulyani dan Maksudi (2018: 156) mengemukakan bahwa "sosial merupakan tindakan atau aksi dan interaksi seseorang dengan orang lainnya serta melakukan kerjasama untuk mencapai tujuan, yaitu memberikan kontribusi kepada masyarakat". Selain itu, Mulawarman dan Nurfitri (2017: 37) menyatakan kata "sosial" diartikan sebagai "kenyataan sosial bahwa setiap individu melakukan aksi yang memberikan kontribusi kepada masyarakat". Jadi dapat disimpulkan bahwa media sosial adalah suatu alat atau perantara yang digunakan untuk berinteraksi dan berkomunikasi antara seseorang dengan orang lain yang banyak memberikan kontribusi atau manfaat bagi masyarakat. Beberapa media sosial menurut Triastuti, dkk. (2017) yaitu facebook, instagram, twitter, youtube, whatsapp, line, google plus, wattpad, telegram, BBM, blog, skype, kakao talk.

Dampak Media Sosial Bagi Anak

Perkembangan media sosial tentu saja membawa banyak dampak, baik itu dampak 
positif maupun negatif terhadap pendidikan anak terutama motivasi belajar anak. Menurut Khairuni (2016) media sosial memiliki dampak positif dan negatif bagi anak yaitu:

1) Dampak positif media sosial diantaranya anak dapat belajar bagaimana cara beradaptasi, bersosialisasi dengan publik dan mengelola jaringan pertemanan, serta memudahkan anak dalam kegiatan belajar karena dapat digunakan sebagai sarana untuk berdiskusi dengan teman mengenai tugas-tugas sekolah mereka.

2) Adapun dampak negatif penggunaan media sosial terhadap pendidikan anak juga sangat banyak diantaranya dapat dilihat dari banyaknya anak yang menggunakannya bukan untuk belajar tetapi untuk kesibukan mereka di jejaring sosial misalnya facebook, twitter, instagram dan lainnya hingga membuat anak lalai terhadap tugas-tugasnya membuat anak-anak ini kurang displin dan mudah mencontek karya-karya orang lain.

\section{Indikator Penggunaan Akun Media Sosial}

Menurut Rasyidah (2017: 63), indikator penggunaan media sosial sebagai berikut:

1) Alokasi waktu mengakses media sosial

2) Akun media sosial yang dimiliki

3) Kegunaan/ alasan menggunakan media sosial

4) Dampak positif dan negatif penggunaan media sosial

\section{Definisi Motivasi Belajar}

Istilah motivasi berasal dari kata motif yang dapat diartikan sebagai kekuatan yang terdapat dalam diri individu, yang menyebabkan individu tersebut bertindak atau berbuat. Menurut Mariskhana (2018) motivasi dapat dikatakan sebagai suatu perubahan energi dari dalam diri seseorang yang ditandai dengan munculnya feeling dan didahului dengan tanggapan terhadap adanya tujuan. Uno (2014: 9) menyatakan bahwa:

Motivasi merupakan suatu dorongan yang timbul oleh adanya rangsangan dari dalam maupun dari luar sehingga seseorang berkeinginan untuk mengadakan perubahan tingkah laku / aktivitas tertentu lebih baik dari keadaan sebelumnya. Dengan sasaran sebagai berikut: (a) mendorong manusia untuk melakukan suatu aktivitas yang didasarkan atas pemenuhan kebutuhan. Dalam hal ini, motivasi merupakan motor penggerak dari setiap kebutuhan yang akan dipenuhi, (b) menentukan arah tujuan yang hendak dicapai, dan (c) menentukan perbuatan yang harus dilakukan.

Berdasarkan pengertian motivasi dari beberapa ahli, maka dapat disimpulkan bahwa motivasi adalah sesuatu yang mendorong seseorang, baik yang berasal dari dalam maupun dari luar yang mempengaruhinya untuk melakukan sesuatu.

Motivasi dan belajar merupakan dua hal yang saling memengaruhi. Belajar merupakan komponen dalam ilmu pendidikan yang berkaitan dengan tujuan dan bahan acuan interaksi, baik yang bersifat eksplisit maupun implisit. Komara (2014) mengemukakan bahwa dalam pengaplikasiannya, belajar adalah kegiatan seseorang untuk memperoleh pengetahuan, perilaku, dan keterampilan dengan cara mengolah bahan belajar. Sementara menurut Uno (2014: 23) "belajar adalah perubahan tingkah laku secara relatif permanen dan secara potensial terjadi sebagai hasil dari praktik atau penguatan (reinforced practice) yang dilandasi tujuan untuk mencapai tujuan tertentu". Berdasarkan beberapa pendapat ahli tentang definisi belajar, maka dapat disimpulkan bahwa belajar adalah suatu kegiatan dalam pengumpulan informasi atau pengetahuan sehingga menimbulkan perubahan positif pada diri seseorang dari segi kognitif/pengetahuan, afektif/sikap dan psikomotor/ keterampilan.

Berdasarkan beberapa pendapat ahli tentang definisi motivasi dan belajar, maka beberapa ahli juga mengemukakan definisi dari motivasi belajar. Menurut Siam, dkk. (2015) motivasi belajar merupakan kekuatan (power motivation), daya pendorong (driving force) atau alat pembangun kesediaan dan keinginan yang kuat dalam diri peserta didik untuk belajar secara aktif, kreatif, inovatif, dan menyenangkan dalam rangka perubahan perilaku, baik dalam aspek kognitif, afektif, maupun psikomotor. Sedangkan menurut Azis (2017) motivasi belajar adalah suatu dorongan dari dalam diri yang disadari untuk melakukan aktivitas-aktivitas belajar anak guna mencapai sebuah tujuan tertentu yang mengakibatkan perubahan-perubahan prestasi belajar. Berdasarkan beberapa pendapat ahli di atas dapat disimpulkan bahwa motivasi belajar adalah sebuah dorongan, baik itu yang berasal dari dalam diri seseorang maupun dari luar diri seseorang yang mempengaruhi aktivitas pencarian pengetahuan, perubahan perilaku dan keterampilan. 


\section{Jenis Motivasi}

Menurut Uno (2014) dilihat dari sudut sumber yang menimbulkannya, motif dibedakan menjadi dua macam, yaitu motif intrinsik dan ekstrinsik. Motif instrinsik, timbul dari dorongan dalam diri sendiri sehingga tidak memerlukan adanya rangsangan atau pengaruh dari luar. Sedangkan motif ekstrinsik timbul karena adanya pengaruh dari luar individu. Motif intrinsik lebih kuat dari motif ekstrinsik, oleh karena itu pendidikan harus berusaha menimbulkan motif intrinsik dengan menumbuhkan dan mengembangkan minat mereka terhadap bidang-bidang studi yang relevan.

Motivasi belajar dapat timbul karena faktor intrinsik, berupa hasrat dan keinginan berhasil dan dorongan kebutuhan belajar, harapan akan cita-cita. Sedangkan faktor ekstrinsiknya adalah adanya penghargaan, lingkungan belajar yang kondusif, dan kegiatan belajar yang menarik. Kedua faktor tersebut disebabkan oleh rangsangan tertentu, sehingga seseorang berkeinginan untuk melakukan aktivitas belajar yang lebih giat dan semangat.

\section{Fungsi Motivasi}

Menurut Aquami (2015: 49) motivasi sebagai suatu proses mengantarkan siswa kepada pengalaman pengalaman yang memungkinkan mereka dapat belajar. Sebagai proses, motivasi mempunyai fungsi antara lain

1) Mendorong manusia untuk berbuat yaitu sebagai penggerak atau yang memberi semangat dan mengaktifkan siswa agar tetap berminat dan siaga.

2) Menentukan arah perbuatan yakni ke arah tujuan yang hendak dicapai. Atau memuaskan perhatian anak pada tugastugas tertentu yang berhubungan dengan pencapaian tujuan belajar.

3) Menyeleksi perbuatan manusia yaitu menentukan perbuatan-perbuatan apa yang harus dijalankan yang serasi guna mencapai tujuan itu dengan menyampingkan perbuatan-perbuatan yang tidak bermanfaat bagi tujuan itu. Atau membantu memenuhi kebutuhan akan hasil jangka pendek dan hasil jangka panjang.

\section{Ciri- ciri Siswa Memiliki Motivasi Belajar}

Ada beberapa ciri-ciri siswa yang memiliki motivasi belajar yang dikemukakan oleh Emda (2017) sebagai berikut:
1) Tekun menghadapi tugas yaitu mengerjakan tugas hingga selesai

2) Ulet menghadapi kesulitan atau tidak lekas putus asa. Tidak memerlukan dorongan luar untuk berprestasi sebaik mungkin atau tidak lekas puas dengan prestasi yang telah dicapainya

3) Menunjukkan minat terhadap bermacammacam masalah

4) Lebih senang bekerja mandiri

5) Cepat bosan pada tugas-tugas rutin yaitu hal-hal yang bersifat mekanis, berulangulang begitu saja sehingga kurang kreatif.

6) Dapat mempertahankan pendapatnya jika telah yakin akan sesuatu

7) Tidak mudah melepaskan hal yang diyakininya

8) Senang mencari dan memecahkan masalah soal-soal.

\section{Indikator Motivasi Belajar}

Menurut Hamzah B. Uno 2008 (Oktavia, 2018), indikator motivasi belajar dapat diklasifikasikan sebagai berikut:

1) Adanya hasrat dan keinginan berhasil.

2) Adanya dorongan dan kebutuhan dalam belajar.

3) Adanya harapan dan cita-cita masa depan.

4) Adanya penghargaan dalam belajar.

5) Adanya kegiatan yang menarik dalam belajar.

6) Adanya lingkungan belajar yang kondusif.

\section{Hubungan Penggunaan Media Sosial terhadap Motivasi Belajar}

Proses pembelajaran dapat berjalan dengan efektif dan efisien, jika proses pembelajaran tersebut berhasil membuat anak menambah wawasannya dan memahami materi pembelajaran yang dipelajarinya. Ada banyak hal yang mendukung keberhasilan proses pembelajaran, salah satunya adalah penggunaan media dalam pembelajaran anak. Menurut Tafonao (105: 2018) "Media pembelajaran adalah alat bantu dalam proses belajar mengajar untuk merangsang pikiran, perasaan, perhatian dan kemampuan atau ketrampilan pembelajar sehingga dapat mendorong terjadinya proses belajar". Dengan adanya bantuan media pembelajaran, suatu materi pembelajaran atau ilmu pengetahuan dengan lebih mudah diserap dan dipahami oleh anak-anak.

Media sosial juga merupakan salah satu media yang dapat digunakan untuk mendukung proses belajar anak. Media sosial adalah suatu aplikasi jaringan internet yang 
memungkinkan seseorang dapat berkomunikasi secara tidak langsung dari jarak jauh. Dengan media sosial, seseorang dapat saling berkomunikasi meskipun tidak saling bertatap muka. Kelebihan yang dimiliki media sosial ini sangat banyak. Selain untuk media komunikasi, media sosial juga memungkinkan seseorang untuk mencari berbagai informasi, ilmu pengetahuan, dan hiburan. Dengan demikian, media sosial dapat digunakan sebagai media pembelajaran dan pendidikan. Menurut Fitri (122: 2017) " Media sosial memiliki manfaat positif dalam kemudahan untuk mengakses materi pelajaran untuk tugas sekolah dan bahan diskusi dari materi pelajaran di sekolah".

Peran media sosial sebagai media pembelajaran dan pendidikan dapat membantu meningkatkan motivasi anak dalam belajar. Putra Sumberharjo, dkk. (2015) dalam Tafonao (108: 2018) mengemukakan bahwa "Media mengandung pesan sebagai perangsang belajar dan dapat menumbuhkan motivasi belajar sehingga siswa tidak menjadi bosan dalam meraih tujuan-tujuan belajar". Dengan demikian, media sosial yang digunakan sebagai media dalam proses belajar, dapat membantu meningkatkan motivasi belajar anak.

Koni (2016) mengemukakan bahwa manfaat media sosial terhadap peserta didik diantaranya:

a. Munculnya kemampuan beradaptasi

Melalui media sosial, peserta didik akan mampu belajar cara mengembangkan kemampuan teknis dan sosial yang dibutuhkan mereka dalam menghadapi era digital sekarang ini. Mereka akan bersosialisasi dengan sahabatnya di jejaring sosial, serta kemampuan memanajemen pertemanan mereka.

b. Menambah teman

Melalui media sosial, peserta didik bisa menambah jaringan pertemanannya, menciptakan suatu komunitas yang bermanfaat bagi mereka, entah itu dalam diskusi pelajaran maupun hal-hal lain yang bisa memberikan kontribusi positif bagi mereka para peserta didik. c. Memotivasi peserta didik

Dengan terbentuknya jaringan pertemanan yang luas, ini akan mampu memotivasi para peserta didik dalam proses pengembangan diri melalui diskusi materi pelajaran dan menerima masukan atau saran teman-teman baru mereka yang terhubung melalui aplikasi media sosial.

\section{METODE PENELITIAN}

Penelitian ini menggunakan pendekatan kuantitatif. Jenis penelitian yang digunakan adalah ex-postfacto. Ada 2 jenis variabel dalam penelitian ini yaitu variabel independen dan variabel dependen. Variabel independen dalam penelitian ini yaitu penggunaan media sosial (medsos) dan variabel dependen dalam penelitian ini yaitu motivasi belajar. Desain penelitian yang digunakan adalah criterion group study atau yang biasa disebut causal comparative research. Causal comparative research merupakan penelitian yang mencoba mencari informasi terjadinya hubungan sebab akibat, kemudian berusaha untuk melacak kembali hubungan tersebut. Dalam penelitian ini, variabel-variabel yang ada telah terjadi sebelumnya sehingga tidak perlu diberi perlakuan atau kontrol. Populasi dalam penelitian ini adalah seluruh siswa SD Negeri Perumnas Kecamatan Rappocini Kota Makassar tahun ajaran 2018/2019.

Teknik yang digunakan dalam penelitian ini adalah Kuisioner (angket), Wawancara, Dokumentasi. Sampel yang akan digunakan adalah seluruh siswa kelas IV dan V SD Negeri Perumnas Kecamatan Rappocini Kota Makassar sebanyak 51 orang siswa

\section{HASIL \& PEMBAHASAN}

Pada bagian ini diuraikan hasil analisis data penelitian yakni analisis data statistik deskriptif dan analisis data statistik inferensial yang menjawab pertanyaan pada rumusan masalah dan membuktikan hipotesis penelitian yang sebelumnya telah dipaparkan.

Tabel 1. Distribusi Frekuensi Penggunaan Media Sosial

\begin{tabular}{clccc}
\hline No. & Kategori & Interval & Frekuensi & Persentase (\%) \\
\hline 1 & Sangat Tinggi & $65<$ skor $\leq 80$ & 5 & 9,80 \\
\hline 2 & Tinggi & $50<$ skor $\leq 65$ & 38 & 74,51 \\
\hline 3 & Rendah & $35<$ skor $\leq 50$ & 8 & 15,69 \\
\hline 4 & Sangat Rendah & $20 \leq$ skor $\leq 35$ & 0 & 0 \\
\hline Jumlah & & & 51 & 100 \\
\hline
\end{tabular}




\begin{tabular}{cccccc}
\hline Mean & Median & $\begin{array}{c}\text { Standar } \\
\text { Deviasi }\end{array}$ & Modus & Minimum & Maksimum \\
\hline 57,7647 & 60 & 7,25696 & 60 & 37 & 73 \\
\hline
\end{tabular}

Dari tabel di atas diketahui bahwa persentase tertinggi penggunaan media sosial oleh siswa berada pada kategori tinggi, dengan persentase $74,51 \%$ yaitu sebanyak 38 orang siswa dari jumlah keseluruhan sample yaitu 51 orang. Hal ini berarti, hampir seluruh siswa di kelas IV dan V SD Negeri Perumnas Kecamatan Rappocini Kota Makassar sudah mengenal dan menggunakan media sosial.

Tabel 2 Distribusi Frekuensi Motivasi Belajar

\begin{tabular}{|c|c|c|c|c|}
\hline No. & Kategori & Interval & Frekuensi & Persentase (\%) \\
\hline 1 & Sangat Tinggi & $65<$ skor $\leq 80$ & 29 & 56,86 \\
\hline 2 & Tinggi & $50<$ skor $\leq 65$ & 20 & 39,22 \\
\hline 3 & Rendah & $35<$ skor $\leq 50$ & 2 & 3,92 \\
\hline 4 & Sangat Rendah & $20 \leq$ skor $\leq 35$ & 0 & 0 \\
\hline Jumlah & & & 51 & 100 \\
\hline Mean & Median & $\begin{array}{c}\text { Standar } \\
\text { Deviasi }\end{array}$ & Modus & Maksimum \\
\hline 65,7255 & 67 & 7,38398 & 67 & 48 \\
\hline
\end{tabular}

Dari tabel di atas dketahui bahwa secara keseluruhan motivasi belajar siswa kelas IV dan V di SD Negeri Perumnas Kecamatan Rappocini Kota Makassar berada pada kategori tinggi sampai dengan sangat tinggi dengan persentase 96,08\%. Dengan demikian, penggunaan media sosial secara baik dan positif oleh siswa dapat membawa dampak positif bagi siswa yaitu memotivasi siswa dalam pembelajaran.

Distribusi data dikatakan normal apabila hasil analisis diperoleh nilai signifikansi > 0,05, sedangkan apabila hasil analisis diperoleh nilai signifikansi $<0,05$ maka menunjukkan data tidak normal. Berdasarkan uji normalitas pada lampiran , diperoleh hasil seperti pada tabel berikut ini:

Tabel 3 Ringkasan Hasil Uji Normalitas Data Penelitian

\begin{tabular}{lccc}
\hline \multicolumn{1}{c}{ Variabel } & $\begin{array}{c}\text { Nilai } \\
\text { Kolmogorov } \\
\text { Smirnov }\end{array}$ & $\begin{array}{c}\text { Nilai } \\
\text { Signifikansi }\end{array}$ & Kesimpulan \\
\hline Penggunaan Media Sosial & 1,214 & 0,105 & Normal \\
\hline Motivasi Belajar & 0,839 & 0,482 & Normal \\
\hline
\end{tabular}

Hubungan antara kedua variabel dapat dikatakan linear jika hasil analisis diperoleh nilai signifikansi deviation from linearity > 0,05 , sedangkan jika hasil analisis diperoleh nilai signifikansi deviation from linearity < 0,05 maka menunjukkan hubungan antara kedua variabel dikatakan tidak linear. Selain itu, hubungan antara kedua variabel dapat ditentukan dengan membandingkan $\mathrm{F}_{\text {hitung }}$ dan $\mathrm{F}_{\text {tabel. }}$. Jika $\mathrm{F}_{\text {hitung }}<\mathrm{F}_{\text {tabel }}$ maka dapat dikatakan bahwa hubungan antara variabel independen dan dependen linear. Berdasarkan uji linearitas pada lampiran, diperoleh hasil seperti pada tabel berikut ini:

Tabel 4 Ringkasan Hasil Uji Linearitas Data Penelitian

\begin{tabular}{lccccc}
\hline \multicolumn{2}{c}{ Variabel } & F hitung & F tabel & $\begin{array}{c}\text { Nilai Signifikansi } \\
\text { (Deviation from } \\
\text { linearity) }\end{array}$ & Kesimpulan \\
\hline $\begin{array}{l}\text { Penggunaan } \\
\begin{array}{l}\text { Sosial dan } \\
\text { belajar }\end{array}\end{array}$ & $\begin{array}{c}\text { Media } \\
\text { Motivasi }\end{array}$ & 0,879 & 1,93 & 0,618 & Linear \\
\hline
\end{tabular}


Tabel 5 Hasil Analisis Regresi

\begin{tabular}{lrrrrrr}
\hline & \multicolumn{2}{c}{$\begin{array}{c}\text { Unstandardized } \\
\text { Coefficients }\end{array}$} & \multicolumn{2}{c}{$\begin{array}{c}\text { Standardized } \\
\text { Coefficients }\end{array}$} & & \\
\cline { 2 - 5 } Model & $\mathrm{B}$ & Std. Error & Beta & $\mathrm{T}$ & Sig. \\
\hline 1 & $\begin{array}{l}\text { (Constant) } \\
\text { Penggunaan } \\
\text { Medsos }\end{array}$ & 33.374 & 7.064 & & 4.724 & .000 \\
\hline
\end{tabular}

a. Dependent Variable:

Motivasi Belajar

Dari tabel 5 dapat diketahui bahwa nilai contant (a) sebesar 33,374, sedangkan nilai variabel independen (penggunaan media sosial) (b)/koefisien regresi sebesar 0,560, sehingga persamaan regresinya dapat dituliskan:

$\mathrm{Y}^{\prime}=\mathrm{a}+\mathrm{bX}$

$Y^{\prime}=33,374+0,560$

Persamaan tersebut menunjukkan bahwa nilai konstanta sebesar 33,374 mengandung arti bahwa nilai konsisten variabel motivasi belajar adalah sebesar 33,374. Nilai koefisien regresi X sebesar 0,560 menunjukkan bahwa setiap penambahan $1 \%$ nilai variabel penggunaan media sosial, maka nilai variabel motivasi belajar bertambah sebesar 0,560. Koefisien regresi tersebut bernilai positif, sehingga dapat dikatakan bahwa arah pengaruh variabel penggunaan media sosial terhadap variabel motivasi belajar adalah positif.

Tabel 6 ANOVA (Uji Nilai Signifikan)

\begin{tabular}{llrrrrr}
\hline Model & & Sum of & & & & \\
\hline 1 & Squares & Df & Mean Square & \multicolumn{1}{c}{ F } & Sig. \\
\hline & Regression & 825.906 & 1 & 825.906 & 21.297 & $.000^{\mathrm{a}}$ \\
& Residual & 1900.250 & 49 & 38.781 & & \\
& Total & 2726.157 & 50 & & & \\
\hline
\end{tabular}

a. Predictors: (Constant), Penggunaan Medsos

b. Dependent Variable: Motivasi Belajar

Pada tabel 6 ANOVA digunakan untuk menentukan taraf signifikansi dari regresi. Kriteria dapat ditentukan berdasarkan uji nilai signifikansi (Sig), dengan ketentuan jika nilai Sig $<0,05$. Berdasarkan tabel di atas, diperoleh nilai Sig $=0,000$, berarti Sig $<$ dari kriteria signifikansi $(0,05)$. Dengan demikian model persamaan regresi berdasarkan data penelitian adalah signifikan atau memenuhi kriteria.

Tabel 7 Koefisien Korelasi

\begin{tabular}{lrrrr}
\hline Model & $\mathrm{R}$ & $\mathrm{R}$ Square & $\begin{array}{c}\text { Adjusted R } \\
\text { Square }\end{array}$ & $\begin{array}{c}\text { Std. Error of } \\
\text { the Estimate }\end{array}$ \\
\hline 1 & $.550^{\mathrm{a}}$ & .303 & .289 & 6.22741 \\
\hline a. Predictors: (Constant), Penggunaan Medsos
\end{tabular}

Tabel 7 di atas menunjukkan besarnya nilai koefisien korelasi/ hubungan (R) yaitu sebesar 0,550. Nilai ini dapat diinterpretasikan bahwa hubungan kedua variabel penelitian berada pada kategori sedang. Melalui tabel di atas juga diperoleh nilai $\mathrm{R}$ Square atau koefisien determinasi yang menunjukkan seberapa bagus model regresi yang dibentuk oleh interaksi variabel bebas dan variabel terikat. Nilai koefisien determinasi yang diperoleh adalah 30,3 \%. Sehingga dapat ditafsirkan bahwa variabel bebas (X) memiliki pengaruh kontribusi sebesar 30,3\% terhadap variabel terikat $(\mathrm{Y})$. 
Tabel 8 Hasil Uji t

\begin{tabular}{|c|c|c|c|c|c|c|}
\hline \multirow{2}{*}{\multicolumn{2}{|c|}{ Model }} & \multicolumn{2}{|c|}{$\begin{array}{c}\text { Unstandardized } \\
\text { Coefficients }\end{array}$} & \multirow{2}{*}{$\begin{array}{c}\text { Standardized } \\
\text { Coefficients }\end{array}$} & \multirow[b]{2}{*}{$\mathrm{T}$} & \multirow[b]{2}{*}{ Sig. } \\
\hline & & B & Std. Error & & & \\
\hline \multirow[t]{2}{*}{1} & (Constant) & 33.374 & 7.064 & & 4.724 & .000 \\
\hline & $\begin{array}{l}\text { Penggunaan } \\
\text { Medsos }\end{array}$ & .560 & .121 & .550 & 4.615 & .000 \\
\hline
\end{tabular}

Berdasarkan tabel 8 diperoleh nilai $\mathrm{t}_{\text {hitung }}$ sebesar 4,615 > $\mathrm{t}_{\text {tabel }} 2,009$ sedangkan signifikansi sebesar $0,000<0,05$, sehingga dapat disimpulkan bahwa variabel penggunaan media sosial secara positif berpengaruh terhadap variabel motivasi belajar.

Tabel 9 Koefisien Determinasi

\begin{tabular}{lrrrr}
\hline Model & $\mathrm{R}$ & $\mathrm{R}$ Square & $\begin{array}{c}\text { Adjusted R } \\
\text { Square }\end{array}$ & $\begin{array}{c}\text { Std. Error of } \\
\text { the Estimate }\end{array}$ \\
\hline 1 & $.550^{\mathrm{a}}$ & .303 & .289 & 6.22741 \\
\hline a. Predictors: (Constant), Penggunaan Medsos
\end{tabular}

Berdasarkan tabel 9 di atas, diketahui $\mathrm{r}_{\text {hitung }}$ sebesar 0,550 maka selanjutnya untuk mengetahui seberapa besar pengaruh variabel independen terhadap variabel dependen dengan menggunakan koefisien determinasi $\mathrm{r}^{2}$ yang dinyatakan dalam persentase.

Hasilnya sebagai berikut:

$$
\begin{aligned}
\mathrm{R}^{2} & =(0,550)^{2} \times 100 \% \\
& =0,303 \times 100 \% \\
& =3,03 \%
\end{aligned}
$$

Berdasarkan perhitungan di atas maka dapat disimpulkan bahwa ada variabel independen berpengaruh terhadap variabel dependen sebesar 30,3\% dan selebihnya 69,7 $\%$ dipengaruhi oleh faktor lain yang tidak diteliti dalam penelitian ini.

Berdasarkan hasil olah data hasil penelitian diperoleh hasil analisis statistik deskriptif dan analisis statistik inferensial. Pada tabel 4.1 menunjukkan hasil analisis statistik deskriptif dari variabel independen yang dalam hal ini adalah penggunaan media sosial dikalangan siswa. Data hasil penelitian tersebut menunjukkan bahwa rata-rata skor penggunaan media sosial siswa adalah 57,7647 dari skor ideal 80. Nilai standar deviasinya sebesar 7,25696. Pengkategorian penggunaan media sosial dibagi menjadi 4 yaitu sangat rendah, rendah, tinggi, dan sangat tinggi. Untuk kategori sangat rendah, tidak ada siswa yang berada dalam kategori tersebut, sedangkan 8 orang siswa $(15,69 \%$ dari 51 siswa) berada pada kategori rendah, 38 orang siswa $(74,51 \%$ dari 51 siswa) yang berada pada kategori tinggi dan sebanyak 5 orang siswa $(9,8 \%$ dari 51 siswa) penggunaan media sosialnya berada pada kategori sangat tinggi. Hal ini menunjukkan bahwa penggunaan media sosial oleh siswa kelas IV dan V SD Negeri Perumnas Kecamatan Rappocini Kota Makassar berada pada kategori tinggi. Dengan demikian, perlu adanya pengawasan dari lingkungan sekitar siswa untuk memberikan arahan yang positif dalam penggunaan media sosial, baik dari pihak sekolah dan utamanya orangtua agar media sosial dapat dimanfaatkan dengan baik sebagai media belajar anak karena tidak dapat dipungkiri bahwa media sosial adalah aplikasi berbasis internet yang bersifat bebas dan terbuka yang dapat memberikan dampak yang besar terhadap anak. Namun, jika penggunaannya diarahkan kepada hal yang positif seperti media belajar, maka dapat membantu meningkatkan motivasi belajar anak dan akan membawa dampak positif terhadap anak. Chalim dan Anwas (2018) mengemukakan bahwa peran orangtua sebagai lingkungan keluarga yang paling dekat dengan anak sangat penting dalam menciptakan lingkungan yang kondusif agar anak-anak memanfaatkan internet secara positif dan dari lingkungan sekolah, guru memiliki peran penting dalam membimbing dan mengarhkan peserta didik agar mampu memanfaatkan internet sebagai media pembelajaran. 
Hasil analisis deskriptif pada penjelasan diatas menunjukkan tingkat penggunaan media sosial di SD Negeri Perumnas Kecamatan Rappocini Kota Makassar yang berada pada kategori tinggi, hal ini sejalan dengan hasil wawancara yang telah dilakukan dengan pihak sekolah, dalam hal ini adalah guru atau wali kelas di kelas IV dan V. Narasumber menjelaskan bahwa para siswa di kelas mereka memang sudah ada yang mengenal dan mengakses media sosial. Media sosial yang biasa diakses adalah jejaring sosial seperti facebook dan aplikasi whatsapp atau line. Namun dalam pengaksesan media sosial ini, tidak pernah didapati adanya siswa yang mengakses media sosial di lingkungan sekolah karena pihak sekolah memberi aturan untuk tidak membawa smartphone ke sekolah, kecuali untuk keperluan mendesak seperti untuk menghubungi orangtua siswa bagi mereka yang memiliki jarak rumah yang jauh dari sekolah, sehingga mereka dapat dijemput oleh orangtuanya saat jam pulang sekolah. Selain itu, sebagai pendidik guru memberikan aturan dalam kelas untuk menggunakan media sosial hanya 2 kali sepekan atau dihari libur, jika tidak diperlukan dalam kegiatan belajar di rumah.

Hasil analisis statistik deskriptif dari variabel dependen yakni motivasi belajar siswa, pada tabel 4.2 menunjukkan bahwa ratarata skor motivasi belajar siswa adalah 65,7255 dari skor ideal 80. Nilai standar deviasinya adalah sebesar 7,38398. Pengkategorian motivasi belajar siswa juga dibagi menjadi 4 yaitu sangat rendah, rendah, tinggi, dan sangat tinggi. Untuk kategori sangat rendah, tidak ada siswa yang berada dalam kategori tersebut, sedangkan sebanyak 2 orang siswa $(3,92 \%$ dari 51 siswa) berada pada kategori rendah, sebanyak 20 orang siswa $(39,22 \%$ dari 51 siswa) berada pada kategori tinggi dan sebanyak 29 orang $(56,86 \%$ dari 51 siswa) motivasi belajarnya berada pada kategori sangat tinggi. Dengan demikian dapat dikatakan bahwa siswa kelas IV dan V SD Negeri Perumnas Kecamatan Rappocini Kota Makassar memiliki motivasi belajar yang sangat baik. Hal ini menunjukkan bahwa penggunaan media sosial secara baik dan bijak dapat membawa dampak yang positif bagi peserta didik. Meski demikian, tetap perlu adanya dorongan yang positif dari lingkungan sekitar siswa seperti guru, orangtua dan terutama diri mereka sendiri untuk mengimplementasikan dorongan semangat belajar dalam diri mereka sehingga memperoleh prestasi belajar yang semakin baik.

Hasil analisis deskriptif pada penjelasan diatas menunjukkan tingkat motivasi belajar di SD Negeri Perumnas Kecamatan Rappocini Kota Makassar berada pada kategori sangat tinggi, hal ini berarti sebagian besar siswa kelas IV dan V SD Negeri Perumnas Kecamatan Rappocini Kota Makassar memiliki motivasi belajar yang sangat baik. Hasil analisis tersebut juga sejalan dengan hasil wawancara yang telah dilakukan dengan pihak sekolah, di mana narasumber mengemukakan bahwa mengenai dampak positif dan negatif dari penggunaan akun media sosial dikalangan siswa tidak terlihat besar secara signifikan. Meskipun tidak dapat dipungkiri ada juga beberapa siswa yang mungkin tergolong kecanduan dalam bermedia sosial, namun sebagian besar siswa masih dapat mempertahankan motivasi belajar mereka. Hal ini mungkin dikarenakan para siswa telah diberikan saran dan arahan oleh wali kelas mereka untuk mengakses media sosial hanya 2 kali saja dalam sepekan bagi mereka yang memiliki kebiasaan menggunakan dan mengakses media sosial. Untuk siswa yang mungkin telah kecanduan dalam bermedia sosial, diharapkan kepada lingkungan paling dekat bagi siswa yang dalam hal ini adalah orangtua dan keluarga siswa, untuk memberikan arahan dan dukungan dalam penggunaan smartphone dan media sosial.

Berdasarkan hasil pengujian hipotesis menggunakan analisis regresi linear sederhana diketahui besarnya nilai korelasi/ hubungan (R) antara kedua variabel yaitu sebesar 0,550 atau sama dengan 55\%. Sedangkan koefisien determinasinya (R Square) sebesar 0,303 yang menunjukkan bahwa pengaruh variabel independen (penggunaan media sosial) terhadap variabel dependen (motivasi belajar) adalah sebesar $30,3 \%$. Kemudian, berdasarkan nilai signifikansi dari tabel 4.8 diperoleh nilai signifikansi sebesar $0,000<0,05$, dan nilai $t$ diketahui nilai $\mathrm{t}_{\text {hitung }}$ sebesar 4,615 $>\mathrm{t}_{\text {tabel }} 2,009$, sehingga dapat disimpulkan bahwa penggunaan media sosial secara bijak berpengaruh terhadap variabel motivasi belajar siswa SD Negeri Perumnas Kecamatan Rappocini Kota Makassar. Selain itu, nilai koefisien regresi pada tabel 4.8 bernilai positif yaitu 0,560 , sehingga dapat dikatakan bahwa arah pengaruh variabel penggunaan media sosial terhadap varaibel motivasi belajar adalah positif. Hal ini sejalan dengan hasil penelitian 
Permana (2018) yang mengemukakan bahwa hasil analisis motivasi belajar siswa dengan menggunakan angket motivasi dan dideskripsikan antar kelas perlakuan dengan kelas kontrol, diperoleh rata-rata bahwa kelas perlakuan $(80 \%)$ cenderung lebih tinggi di banding kelas kontrol $(70 \%)$, sehingga dapat disimpulkan bahwa terdapat pengaruh penggunaan media sosial sebagai sumber belajar terhadap motivasi belajar.

\section{KESIMPULAN \& SARAN}

Berdasarkan hasil penelitian dan pembahasan, maka dapat disimpulkan bahwa rata-rata skor penggunaan media sosial siswa kelas IV dan V SD Negeri Perumnas Kecamatan Rappocini Kota Makassar berada dalam kategori tinggi sedangkan rata-rata skor motivasi belajar siswa berada dalam kategori sangat tinggi, sehingga penggunaan media sosial secara positif berpengaruh terhadap motivasi belajar siswa kelas IV dan V SD Negeri Perumnas Kecamatan Rappocini Kota Makassar. Berdasarkan hasil penelitian yang telah dikemukakan sebelumnya, maka penelitian ini mengemukakan beberapa saran diantaranya adalah:

1. Kepada siswa, agar mematuhi arahan, bimbingan ataupun aturan dari guru maupun orangtua dalam hal penggunaan handphone dan pengaksesan media sosial, dapat menggunakan handphone dan media sosial dengan bijak (tidak mengakses sesuatu yang bersifat negatif), serta menyadari pentingnya membatasi waktu bermain handphone dan media sosial ini agar tidak menjadi candu dan lupa waktu.

2. Bagi orangtua, untuk memperhatikan kebiasaan-kebiasaan anak di rumah dalam penggunaan handphone dan pengaksesan media sosial dengan mengarahkan pada penggunaan secara bijak.

3. Bagi guru, agar dapat memberikan arahan dan memperhatikan kebiasaan-kebiasaan atau keseharian peserta didik dalam penggunaan handphone khususnya penggunaan akun media sosial, serta tetap memberi dorongan dan memperhatikan motivasi belajar peserta didik baik dari segi proses pembelajaran maupun prestasi belajar peserta didik.

4. Kepada pihak sekolah yang dalam hal ini adalah kepala sekolah, agar memberikan perhatian khusus yang dapat berupa arahan, bimbingan maupun aturan atau tata tertib dalam penggunaan handphone dan akses media sosial oleh peserta didik, sehingga dapat menghindari adanya dampak yang negatif dari penggunaan akun media sosial.

Kepada Pemerintah khususnya yang bergerak dalam bidang pendidikan, agar dapat memberikan batasan-batasan atau aturan secara umum bagi sekolah-sekolah terkhusus sekolah dasar, untuk tidak membolehkan peserta didik membawa dan menggunakan handphone ke sekolah, serta bekerja sama dengan pihak menyedia jasa internet Indonesia untuk menemukan penemuan baru cara mendeteksi pendaftaran akun media sosial anak di bawah umur.

\section{DAFTAR PUSTAKA}

Aquami. (2015). Pengaruh Motivasi Belajar dan Penggunaan Sarana Belajar Terhadap Hasil Belajar Siswa di MA Paradigma Palembang. Istinbath, Vol. 14 (16), 45-69.

Aspari. (2016). Media Sosial Sebagai Media Pembelajaran Bahasa pada Masyarakat Modern. Bogor: Simposium Nasional Ilmu Pengetahuan dan Teknologi.

Azis, A. L. (2017). Pengaruh Motivasi Intrinsik dan Motivasi ekstrinsik Terhadap Prestasi Belajar Ekonomi Bisnis Kelas X Pesertas Didik Kelas X di SMKN 4 Makassar. Universitas Negeri Makassar, Makassar.

Chalim, S., \& Anwas, E. O. M. (2018). Peran Orangtua dan Guru dalam Membangun Internet sebagai Sumber Pembelajaran The Role of Parents and Teachers in Building the Internet as a Source of Learning. Jurnal Penyuluhan, Vol. 14 (1), 42-51.

Emda, A. (2017). Kedudukan Motivasi belajar Siswa dalam Pembelajaran. Lantanida Journal, Vol. 5 (2), 172-182.

Fitri, S. (2017). Dampak Positif dan Negatif Sosial Media Terhadap Perubahan Sosial Anak. Naturalistic: Jurnal Kajian Penelitian Pendidikan Dan Pembelajaran, Vol. 1 (2), 118-123.

Khairuni, N. (2016). Dampak Positif dan Negatif Sosial Media Terhadap Pendidikan Akhlak Anak. Jurnal Edukasi, Vol. 2 (1), 91-106.

Komara, E. (2014). Belajar dan Pembelajaran Interaktif. Bandung: PT. Refika Aditama.

Koni, S. M. (2016). Pengaruh Jejaring Sosial Terhadap Pendidikan Karakter Peserta 
Didik. TADBIR: Jurnal Manajemen Pendidikan Islam, Vol. 4 (2), 37-43.

Mariskhana, K. (2018). Dampak Media Sosial (Facebook) dan Gadget Terhadap Motivasi Belajar. Perspektif, Vol. 16 (1), 62-67.

Mulawarman, \& Nurfitri, A. D. (2017). Perilaku Pengguna Media Sosial beserta Implikasinya Ditinjau dari Perspektif Psikologi Sosial Terapan. Buletin Psikologi, Vol. 25 (1), 36 - 44.

Oktavia, F. (2018). Pengaruh Penggunaan Media Pembelajaran Tehadap Motivasi Belajar Mata Pelajaran AlQur'an Hadits Siswa Kelas VIII MTs N 6 Boyolali Tahun Pelajaran 2017/2018. Institut Agama Islam Negeri Surakarta, Surakarta.

Permana, E. P. (2018). Pengaruh Media Sosial sebagai Sumber Belajar IPS Terhadap Motivasi Belajar, Kemampuan Berpikir Kritis dan Berpikir Kreatif Siswa Sekolah Dasar. Jurnal PINUS, Vol. 4 (1), 54-59.

Rasyidah, D. S. (2017). Pengaruh Penggunaan Media Sosial dan Jenis-jenis Media Sosial Terhadap Intensitas Belajar PAI SIiswa Kelas VIII di SMPN 3 Karangdowo Klaten Tahun Pelajaran 2016/2017. Institut Agama Islam Negeri Surakarta, Surakarta.

Ratnamulyani, I. A., \& Maksudi, B. I. (2018). Peran Media Sosial dalam Peningkatan Partisipasi Pemilih Pemula Dikalangan Pelajar di Kabupaten Bogor. Jurnal Ilmu-Ilmu Sosial Dan Humaniora, 20 (2), 154-161.

Rohani, A. (2014). Media Instruksional Edukatif. Jakarta: Rineka Cipta.

Siam, K. N., Ason, Y., \& Tirsa, A. (2015). Penggunaan media Nyata untuk Meningkatkan motivasi Belajar Bahasa Indonesia Siswa Kelas VI Sekolah Dasar. Jurnal Pendidikan Dasar, Vol. 3 (2), 166-174.

Sugiyono. (2015). Metodologi Penelitian Pendidikan Pendekatan Kuantitatif, Kualitatif dan R\&D. Bandung: Alfabeta.

Survei APJII. (2017). Laporan Survei APJII 2017. Retrieved March 27, 2019, from https://web.kominfo.go.id/sites/default/ files/Laporan\%20Survei\%20APJII_20 17_v1.3.pdf

Survei APJII. (2019). Hasil Survei APJII (Asosiasi Penyelenggara Jasa Internet Indonesia [Http]. Retrieved from https://tekno.kompas.com/read/2019/0

5/16/03260037/apjii-jumlah-

pengguna-internet-di-indonesiatembus-171-juta-jiwa

Tafonao, T. (2018). Peranan Media Pembelajaran dalam Meningkatkan Minat Belajar Mahasiswa. Jurnal Komunikasi Pendidikan, Vol. 2 (2), 103-114.

Triastuti, E., Prabowo, D. A. I., \& Nurul, A. (2017). Kajian Dampak Penggunaan Media Sosial Bagi Anak dan Remaja. Depok: PUSKAKOM.

Undang-undang Republik Indonesia No. 19 Tahun 2016 tentang perubahan atas undang-undang No. 11 Tahun 2008 tentang Informasi dan Transaksi Elektronik. (2016). Retrieved March 25, 2019, from https://web.kominfo.go.id/sites/default/ files/users/4761/UU\%2019\%20Tahun $\% 202016 . p d f$

Uno, H. B. (2014). Teori Motivasi dan Pengukurannya Analisis di Bidang Pendidikan. Jakarta: Bumi Aksara. 